\title{
LOSS OF WEIGHT IN DRY-SALTING OF FISH.
}

\author{
O. E. NiKKILÄ \\ Laboratory of Tuko OY, Turku, Finland.
}

Received 21th August 1951.

The preservation of fish by salting is still the principal method used in many countries. Salt itself does not act so much as a preservative, but rather by removing water from the fish. By osmosis and probably also as a result of coagulation of proteins, although this question has not been settled, water exudes through the cell walls and salt passes in until equilibrium is attained and the concentration of salt within the cell is equal to that of the external brine. The water content is thus reduced to a point where bacterial and enzymatic actions are arrested or reduced to a very small rate.

The lowering of the water content in fish flesh resulting in a loss of weight depends on many factors such as the size, the freshness and the fat content of the fish. The author (1950) has previously shown that the fat content has very great effect on the rate of fish salting. This paper gives an account of investigations on the dry-salting of fish with various salt amounts.

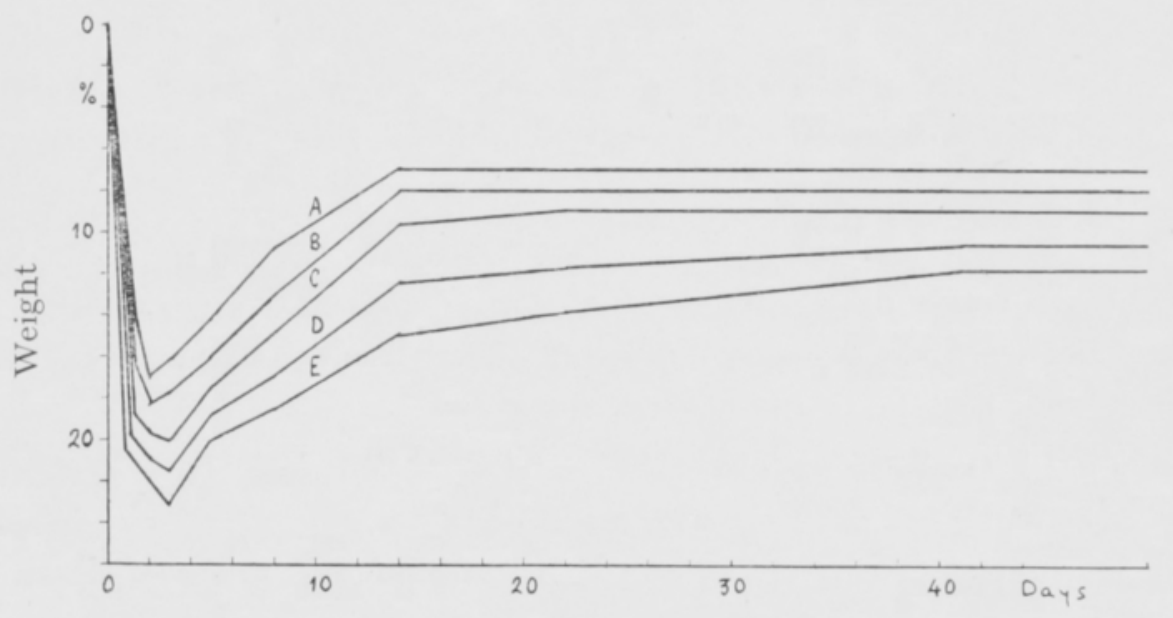

Fig. 1. Loss of weight in dry-salting.

Baltic herring treated with $10 \mathrm{~kg}$. (A), $15 \mathrm{~kg}$ (B), $20 \mathrm{~kg}$. (C), $25 \mathrm{~kg}$. (D), and $30 \mathrm{~kg}$. (E) of sodium chloride per $100 \mathrm{~kg}$. Storage temperature $10^{\circ} \mathrm{C}$. 


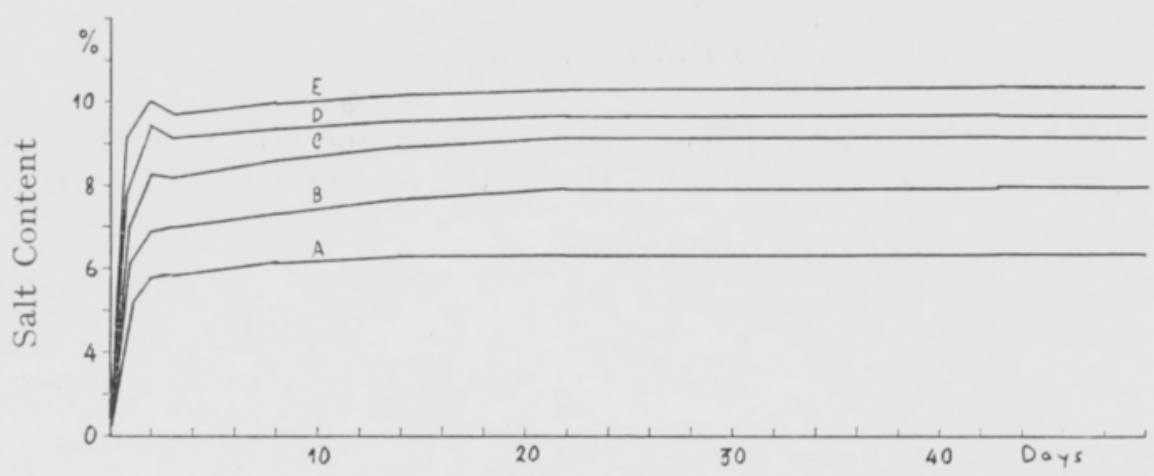

Fig. 2. Content of $\mathrm{NaCl}$ in fish flesh in dry-salting.

Baltic herring treated with $10 \mathrm{~kg}$. (A), $15 \mathrm{~kg}$. (B), $20 \mathrm{~kg}$. (C), $25 \mathrm{~kg}$. (D), and $30 \mathrm{~kg}$. (E) of sodium chloride per $100 \mathrm{~kg}$. Storage temperature $10^{\circ} \mathrm{C}$.

\section{Procedure.}

Fresh Baltic herring (a variety of Clupea harengus) with an average fat content of 3.6 per cent and a mean weight of $34 \mathrm{~g}$. (length $12-18 \mathrm{~cm}$.) were salted with various amounts of dry salt and placed in barrels. The salt contents were 10, 15, 20, 25 and $30 \mathrm{~kg}$. of common sodium chloride per $100 \mathrm{~kg}$. of fish. The salted fish were stored at about $10^{\circ} \mathrm{C}$ and the loss in weight, the diffusion of salt into the fish flesh and the change in the concentration of salt in the brine were followed. Figs. 1 and 2 show the results.

\section{Results and discussion.}

The curves in Fig. 1 indicate that the loss of weight is the greater, the higher the ratio of salt to fish. The minimal weight is reached during 2 days when the fish were treated with 10 or $15 \mathrm{~kg}$. salt per $100 \mathrm{~kg}$. of fish, but 3 days were required with the higher salt ratios. The maximal weight losses with increasing salt ratios were as follows: 17.0, 18.4, 20.0, 21.6, and 23.2 per cent of the fresh weight. After this the weights begin to rise gradually. Fish treated with 10 or $15 \mathrm{~kg}$. of salt per $100 \mathrm{~kg}$. increases in weight during two weeks and attains a constant weight, which is 7 to 8 per cent less than its fresh weight. In the cases where the fish were stored with 20,25 , or $30 \mathrm{~kg}$. of salt per $100 \mathrm{~kg}$. constant weights were attained during a period of from 3 to 6 weeks, the weight losses being $9.0,10.6$ and 11.8 per cent of the frest weight respectively.

Immediately after the beginning of the salt treatment, the content of sodium chloride in the fish tissue begins to rise rapidly, but increases later more evenly (Fig. 2).

Fish salted with 30 or $25 \mathrm{~kg}$. of salt per $100 \mathrm{~kg}$. of fish was of good quality. Fish prepared with $20 \mathrm{~kg}$. of salt per $100 \mathrm{~kg}$. and stored at $10^{\circ} \mathrm{C}$ was in satisfactory condition after two months, but when less salt was used, the fish deteriorated gradually, as shown by organoleptic and chemical tests.

On the basis of these results it is possible to calculate in advance the yield of salted fish (Baltic herring), and to determine when the salting has run to an end. 


\section{REFERENCES.}

Niккıl̈̈, O. E. 1950. Rasvapitoisuuden vaikutus kalan suolaantumiseen. Summary: Salting of fish in dependence on its fat content. J. Sci. Arg. Soc. Finland, 22, p. 103-6.

\section{SELOSTUS:}

\section{KALAN KEVENTYMINEN KUIVASUOLAUKSESSA.}

O. E. NiKKILÄ

Tuko OY:n laboratorio, Turku.

Tässä työssä on seurattu painon sekä suola- ja kuiva-ainepitoisuuden muutoksia silakassa, joka on käsitelty eri suurilla määrillä $(10,15,20,25$ ja $30 \mathrm{~kg}$ suolaa per $100 \mathrm{~kg}$ kalaa) ruokasuolaa. Piirrokset 1 ja 2 esittävät saatuja tuloksia. 